\title{
The BioJS article collection of open source components for
} biological data visualisation [version 1; peer review: not peer reviewed]

Manuel Corpas

The Genome Analysis Centre, Norwich Research Park, Norwich, NR4 7UH, UK

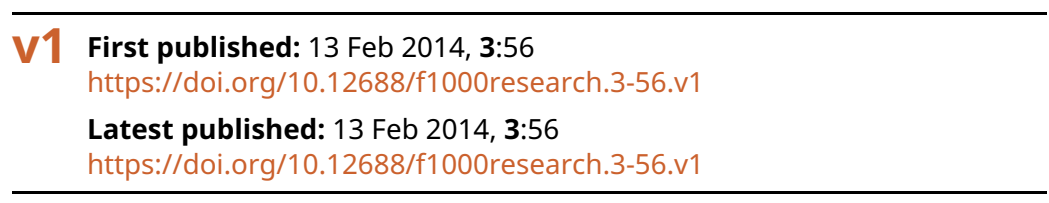

\section{Abstract}

Data-driven research has gained momentum in the life sciences. Visualisation of these data is essential for quick generation of hypotheses and their translation into useful knowledge. BiojS is a new proposed standard for JavaScript-based components to visualise biological data. BioJS is an open source community project that to date provides 39 different components contributed by a global community. Here, we present the BioJS F1000Research collection series. A total of 12 components and a project status article are published in bulk. This collection does not intend to be an allencompassing, comprehensive source of BioJS articles, but an initial set; future submissions from BiojS contributors are welcome.

\section{Not Peer Reviewed \\ This article is an Editorial and has not been}

subject to external peer review.

Any comments on the article can be found at the end of the article.

This article is included in the Bioinformatics

gateway.

This article is included in the BioJS collection. 
Corresponding author: Manuel Corpas (mc@manuelcorpas.com)

Competing interests: No competing interests were disclosed.

Grant information: The author(s) declared that no grants were involved in supporting this work.

Copyright: ( 2014 Corpas M. This is an open access article distributed under the terms of the Creative Commons Attribution License, which permits unrestricted use, distribution, and reproduction in any medium, provided the original work is properly cited. Data associated with the article are available under the terms of the Creative Commons Zero "No rights reserved" data waiver (CC0 1.0 Public domain dedication).

How to cite this article: Corpas M. The BioJS article collection of open source components for biological data visualisation [version 1; peer review: not peer reviewed] F1000Research 2014, 3:56 https://doi.org/10.12688/f1000research.3-56.v1

First published: 13 Feb 2014, 3:56 https://doi.org/10.12688/f1000research.3-56.v1 


\section{Commentary}

Journal articles are a useful source for dissemination of knowledge and attribution of recognition. The F1000Research BioJS article collection provides a sample of BioJS components contributed by the community to date. Articles in this series follow a similar structure to the ones published by the Bioinformatics Journal Application Notes. A description of the component's functionality, design attributes and potential applications are included in each component article of this collection. Each BioJS component article is about two pages long and follows a structure describing its design and implementation, a use case, and potential applications for the component. The use case includes, at least, a figure with a biologically meaningful example and original biological insight. We do not expect every BioJS component to be published in this series; we do encourage, however, all interested BioJS developers to submit articles for peer review if they so wish.

In this initial set of publications we present a) a community article in which we describe the status of the project in $2014^{1}$ and b) a select group of components available through the BioJS registry (http://www.ebi.ac.uk/Tools/biojs/registry/). Components published in this series can be tested in the BioJS registry, with no need to install them first. Components presented in this collection can be grouped according to the type of data they are designed to visualise. According to this criterion, there are components used to visualise sequences, proteins, DNA, networks and phylogenetic trees. There are also some components that visualise a specific type of data linked to a resource. For instance, some widgets use specific data from InterMine ${ }^{2}$, PSICQUIC ${ }^{3}$ or $\mathrm{KEGG}^{4}$. Among those components purposely built to render data visualisations for a particular a resource, we present $K E G G$ Viewer $^{5}$, a component that visualises KEGG pathways; Psicquic Graph ${ }^{6}$, which visualises molecular interactions from PSICQUIC servers, and the InterMine List Analysis ${ }^{7}$ and $T a b l e^{8}$ components, which display statistical analyses and a dynamic result table, respectively, for InterMine-compatible data. Among components not designed for a particular resource, the collection includes FeatureViewer ${ }^{9}$, a component that lays out, maps and renders position-based annotations for protein sequences; HeatMapViewer ${ }^{10}$, which renders matrix-formatted data; treeWidget ${ }^{11}$, a component that visualises phylogenetic trees; a set of components to visualise protein-protein interaction networks ${ }^{12} ;$ DAGViewer ${ }^{13}$, a directed acyclic graph viewer with facilities for rendering ontologies; Sequence ${ }^{14}$, a component for visualising sequences; wigExplorer $^{15}$, which visualises wig format data; and DNAContentViewer ${ }^{16}$, which displays GC/AT content of a DNA sequence. The types of visualisation in this initial set of articles thus include network and directed acyclic graphs, a list, a table, generic features, a heat map, a phylogenetic tree and sequence-based objects.

\section{Summary}

We present the BioJS series articles for the F1000Research BioJS collection. Each component presented in this collection has been previously validated and is readily available for use and testing through the BioJS registry. Every component must follow the minimum standards for documentation, architecture and deposition stated by the project (https://docs.google.com/document/d/1gG036Bvwl4iKX5BTHddGzeE_5eospL-864BrnsAS_s/edit). We encourage potential contributors for BioJS to submit software articles to this collection describing the functionality of valid components.

\section{Acknowledgements}

I am grateful to all contributors to the BioJS project and to the UK's Biotechnology and Biological Sciences Research Council (BBSRC).
1. Corpas M, Jiménez RC, Carbon SJ, et al.: BioJS: an open source standard for biological visualisation - its status in 2014 [v1; ref status: awaiting peer review, http://f1000r.es/2yy]. F1000Research. 2014; 3: 55. Publisher Full Text

2. Smith RN, Aleksic J, Butano D, et al.: InterMine: a flexible data warehouse system for the integration and analysis of heterogeneous biological data. Bioinformatics. 2012; 28(23): 3163-3165. PubMed Abstract | Publisher Full Text | Free Full Text

3. Aranda B, Blankenburg $\mathrm{H}$, Kerrien S, et al:: PSICQUIC and PSISCORE: accessing and scoring molecular interactions. Nat Methods. 2011; 8(7): 528-529. PubMed Abstract | Publisher Full Text | Free Full Text

4. Kanehisa M, Goto S, Sato Y, et al.: Data, information, knowledge and principle: back to metabolism in KEGG. Nucleic Acids Res. 2014; 42(1): D199-205. PubMed Abstract | Publisher Full Text

5. Villaveces JM, Jiménez RC, Habermann BH: KEGGViewer, a BioJS component to visualize KEGG Pathways [v1; ref status: awaiting peer review, http:// f1000r.es/2uq]. F1000Research. 2014; 3: 43 .

Publisher Full Text

6. Villaveces JM, Jiménez RC, Habermann BH: PsicquicGraph, a BioJS component to visualize molecular interactions from PSICQUIC. servers [v1; ref status: awaiting peer review, http://f1000r.es/2up]. F1000Research. 2014; 3: 44. Publisher Full Text

7. Kalderimis A, Stepan R, Sullivan J, et al:: BioJS InterMine List Analysis: A BioJS component for displaying graphical or statistical analysis of collections of items from InterMine endpoints [v1; ref status: awaiting peer review, http://f1000r.es/2ur]. F1000Research. 2014; 3: 45. Publisher Full Text

8. Kalderimis A, Stepan R, Sullivan J, et al: BioJS InterMineTable Component: A BioJS component for displaying data from InterMine compatible webservice endpoints [v1; ref status: awaiting peer review, http://f1000r.es/2us]. F1000Research. 2014; 3: 46. Publisher Full Text

9. Garcia L, Yachdav G, Martin MJ: FeatureViewer, a BioJS component for visualization of position-based annotations in protein sequence [v1; ref status: awaiting peer review, http://f1000r.es/2u2]. F1000Research. 2014; 3: 47. Publisher Full Text

10. Yachdav G, Hecht M, Pasmanik-Chor M, et al:: HeatMapViewer: interactive display of 2D data in biology [v1; ref status: awaiting peer review, http://f1000r. es/2u6]. F1000Research. 2014; 3: 48. Publisher Full Text

11. Schreiber F: treeWidget: a BioJS component to visualise phylogenetic trees [v1; ref status: awaiting peer review, http://f1000r.es/2u4]. F1000Research. 2014; 3: 49 . Publisher Full Text

12. Salazar GA, Meintjes A, Mulder N: PPI layouts: BioJS components for the display of Protein-Protein Interactions [v1; ref status: awaiting peer review, http://f1000r.es/2u5. F1000Research. 2014; 3: 50. Publisher Full Text 
13.

Kalderimis A, Stepan R, Sullivan J, et al:: BioJS DAGViewer: A reusable JavaScript component for displaying directed graphs [v1; ref status: awaiting peer review, http://f1000r.es/2ut]. F1000Research. 2014; 3: 51. Publisher Full Text

14. Gomez J, Jiménez RC: Sequence, a BioJS component for visualising sequences [v1; ref status: awaiting peer review, http://f1000r.es/2v9]. F1000Research. 2014; 3: 52.

Publisher Full Text
15.

Thanki A, Jiménez RC, Kaithakottil GG: wigExplorer, a BioJS componen to visualise wig data [v1; ref status: awaiting peer review, http:// f1000r.es/2vo]. F1000Research. 2014; 3: 53.

Publisher Full Text

16. Thanki A, Caim S, Corpas M: DNAContentViewer: a BioJS component to visualise GC/AT Content [v1; ref status: awaiting peer review, http:// f1000r.es/2xf]. F1000Research. 2014; 3: 54.

Publisher Full Text 
The benefits of publishing with F1000Research:

- Your article is published within days, with no editorial bias

- You can publish traditional articles, null/negative results, case reports, data notes and more

- The peer review process is transparent and collaborative

- Your article is indexed in PubMed after passing peer review

- Dedicated customer support at every stage

For pre-submission enquiries, contact research@f1000.com 